\title{
DEMOTIV ATION OF SECOND SEMESTER ART AND RELIGION FACULTY STUDENTS IN LEARNING ENGLISH LANGUAGE (IAKN AMBON)
}

\author{
ThobiasSarbunan \\ thobialex@yahoo.com
}

Music Art Education Department,Faculty of Art Religion, IAKN Ambon, 97231, Indonesia

\begin{abstract}
This research is aimed to describe demotivation factors which abundant on the level of Maluku university students in learning the English language. In the methodology section, the researcher used descriptive methodology, which sample was twenty-five students on second-semester church and religion department who enrolled in the English language in the second semester. The researcher was collect the data from the accomplishment of student's discovery learning tasks; constructed of footage data of both responses and participation to the online teaching and learning on chatting group of English language class, email database of the second-semester opinion's in learning the English language, and also the participation in online teaching through live streaming on Facebook. In conclusion, those factors which compulsory in English language learners were influence by intrinsic motivation.
\end{abstract}

Keywords:Students Demotivation, Intrinsic and Extrinsic, Learning the English Language.

\section{INTRODUCTION}

The transformation of human beings have been symbolized by civilization, and similar to language development. In deductively, the condition of English language acquisition is widely affected to communicate overseas as an international language. Rohmah. Z., (2005) said that "all of us have been involved in the era of globalization, it is the phenomenon of a multidimensional nature that explicitly and implicitly was variability in all aspects, which stimulate a paradox in form of trend which unified in all aspect"..

In the same way, the notion of the English language has been transformed as an international language or global language and or world language by the needs of people who inferred to run their activities around the world even in the educational system such as study abroad, Rohmah. Z., (2005., p. 2.). In practice, the development of the English language was prominently played by the speaker who derived from a non-native speaker, Mauludin. A. L., as cited in (Moussu\&Llurda., 2008). In the development of the English language to some countries, it will reconstruct a new era of government policy included teaching a foreign language, Mappiasse. S. S. \&Sihes. B. J. A., (September 2014). 
. Moreover, from the perspective of English language teaching, university students were unable to define language learning strategy (LLS) which followed by deterioration of language proficiency even though they were studied over years in each educational level, Tanjung, Z. F., (April, 2018). In that case of language learning strategy, compared to other scholars, it's found that other factors that influenced language learning strategy were compound of individual differences in environment and contextual factors, Nguyen. H.,\& Terry. R. D., (2017). It should be noted that learning and learner variables had been considered to determine the improvement of leaner in comprehend language learning strategy, Nguyen. H.,\& Terry. R. D., (p. 1).

In particular, this previous study found that an appropriate teaching approach that encompassed learning content in teaching materials can be a barrier when isolated to the student's level of language proficiency, Adara. A. R., Nuryadi.,\&Nasution. A. R., (2019). Based on those preliminary studies, this study is focused on university students' demotivate factors which hindering in the level of church music second-semester students in learning the English language.

\subsection{Research Question}

a) What is the context of demotivation in the level of university student's level in learning the English language?

b) What are the factors of the demotivation of university students in learning the English language?

\subsection{Research Purpose:}

This research is aimed to describe demotivation factors which abundant on the level of art and religion faculty students at IAKN Ambon in learning the English language.

\section{LITERATURE REVIEW}

The achievement of an individual has enriched the pathway to the goal is implied to the motivation-which its scope to achieved high performance and also overcoming the barriers, Tohidi. H.,\&Jabbri. M. M., (December, 2012). Besides, psychology vied motivation as a potency that grounds people to behave in particular and also to achieve a point of view, besides that motivation conveys the utmost assistance when in the organization, Tohidi. H.,\&Jabbri. M. M., (p. 1).

In education, motivation can be prescribed as the utility of human behavior, thus motivation is the pathway to react, fulfill, as a trigger, to achieve, and replicated human behavior, in continual of human development; motivation also as the starting point, guidance, and a tool to maintain oriented behavior, so that in other words motivation is the key point to achieve human expectation or needs, Gopalan. V., Bakar. A. A. J., Zulkifli. A. A., Alwi. A.,\& Mat. C. R., (December 2017).

In particular, motivation in learning process had been constructed on based of theories in learning motivation, so that the first theory which underpinned learning motivation is intrinsic and extrinsic 
motivation theory, Legault., L., (November, 2016) that enlighten; intrinsic motivation is the main area of interest, enjoyment, and inherent satisfaction, which implementing "non-instrumental in nature, that is, intrinsically motivated action is not contingent upon any outcome separable from the behavior itself. Rather, the means and ends are the same. For example, a child may play outdoors - running, skipping, jumping - for no other reason than because it is fun and innately satisfying".

On the side of extrinsic motivation, Legault., L., (p. 2) it is concealed to "performance of a behaviour that is fundamentally contingent upon the attainment of an outcome that is separable from the action itself. In other words, extrinsic motivation (EM) is natural instrumental. It is performed to attain some other outcome. For instance, a teenager might wash dishes at home to receive an allowance. Similarly, a student may study for a test to receive a test result". The following description on the table below is types of extrinsic motivation which applied to the example of motivation to regulate racial prejudice (Adapted from Legault et al. 2007) and also for the second figure is the goal of intrinsic and extrinsic motivation on below.

Figure I:

Types of Extrinsic Motivation

\begin{tabular}{|c|c|c|c|}
\hline $\begin{array}{l}\text { Type of Extrinsic } \\
\text { Motivation }\end{array}$ & $\begin{array}{l}\text { Nature of External } \\
\text { Contingency }\end{array}$ & $\begin{array}{l}\text { Underlying Reason for } \\
\text { Behavior }\end{array}$ & Example \\
\hline External Regulation & $\begin{array}{l}\text { Consequences, } \\
\text { incentives, compliance }\end{array}$ & $\begin{array}{l}\text { To receive or avoid a } \\
\text { consequence; to fulfill } \\
\text { an external } \\
\text { requirement }\end{array}$ & $\begin{array}{l}\text { "I avoid making } \\
\text { prejudiced comments } \\
\text { so that other people } \\
\text { will think I'm } \\
\text { nonprejudiced" }\end{array}$ \\
\hline Introjected Regulation & $\begin{array}{l}\text { Feelings of internal } \\
\text { pressure; to avoid guilt } \\
\text { or to boost the ego }\end{array}$ & $\begin{array}{l}\text { Because it "should" be } \\
\text { done }\end{array}$ & $\begin{array}{l}\text { "I avoid acting in a } \\
\text { prejudiced manner } \\
\text { because I would feel } \\
\text { bad about myself if I } \\
\text { didn't" }\end{array}$ \\
\hline Identified Regulation & $\begin{array}{l}\text { Personal valuing of a } \\
\text { behavior, sense of } \\
\text { importance }\end{array}$ & Because it is important & $\begin{array}{l}\text { "I avoid being } \\
\text { prejudiced because it is } \\
\text { an important goal" }\end{array}$ \\
\hline Integrated Regulation & $\begin{array}{l}\text { Expression of self and } \\
\text { identity; congruence } \\
\text { with self and other } \\
\text { values }\end{array}$ & $\begin{array}{l}\text { Because it reflects core } \\
\text { values and self/identity }\end{array}$ & $\begin{array}{l}\text { "I avoid being } \\
\text { prejudiced because I } \\
\text { see myself as a } \\
\text { nonprejudiced person" }\end{array}$ \\
\hline
\end{tabular}

Figure II:

The Goal of Intrinsic and Extrinsic Motivation (Adapted from Medically Review, by Longhurst. S. A., as cited in Legg. J. T., February, 2019)

\begin{tabular}{|l|l|l|}
\hline & Motivation & Goals \\
\hline Intrinsic & $\begin{array}{l}\text { You do the activity because } \\
\text { it's internally rewarding. You } \\
\text { may do it because it's fun, } \\
\text { enjoyable, and satisfying. }\end{array}$ & $\begin{array}{l}\text { Goals come from within and the outcomes } \\
\text { satisfy your basic psychological needs for } \\
\text { autonomy, competence, and relatedness. }\end{array}$ \\
\hline Extrinsic & $\begin{array}{l}\text { You do the activity in order to } \\
\text { get an external reward in } \\
\text { return. }\end{array}$ & $\begin{array}{l}\text { Goals are focused on an outcome and don't } \\
\text { satisfy your basic psychological needs. Goals } \\
\text { involve external gains, such as money, fame, } \\
\text { power, or avoiding consequences. }\end{array}$ \\
\hline
\end{tabular}


Meanwhile, on the main point of teaching the English language in both second and foreign language, motivation has been influenced inadequate to all individual language learner, which is motivation reflected an individual psychology response to the outcast phenomenon; that responses can be described as attitudes, desires, and effort; in other perspectives, motivation is a framework of concerning energy, direction, persistence, and result from the different event which constructed and also act inactivation and intention, Abdi. N. P., (January, 2014).
In learning the English language as a foreign language, there are three theories which underpinned English learner such as, Oletić. A.,\&llić. N., (December, 2014):

a) Expectation-value theory is focused on behavior development in both expectation and value sides'. Moreover, this theory condemned to how an individual actsfromthe perspective of choice, performance, and persistence, Wigfield. A., \& Eccles. S. J., (as cited in Murphy \& Alexander; 2000);

Figure III

Expectation-Value Theory

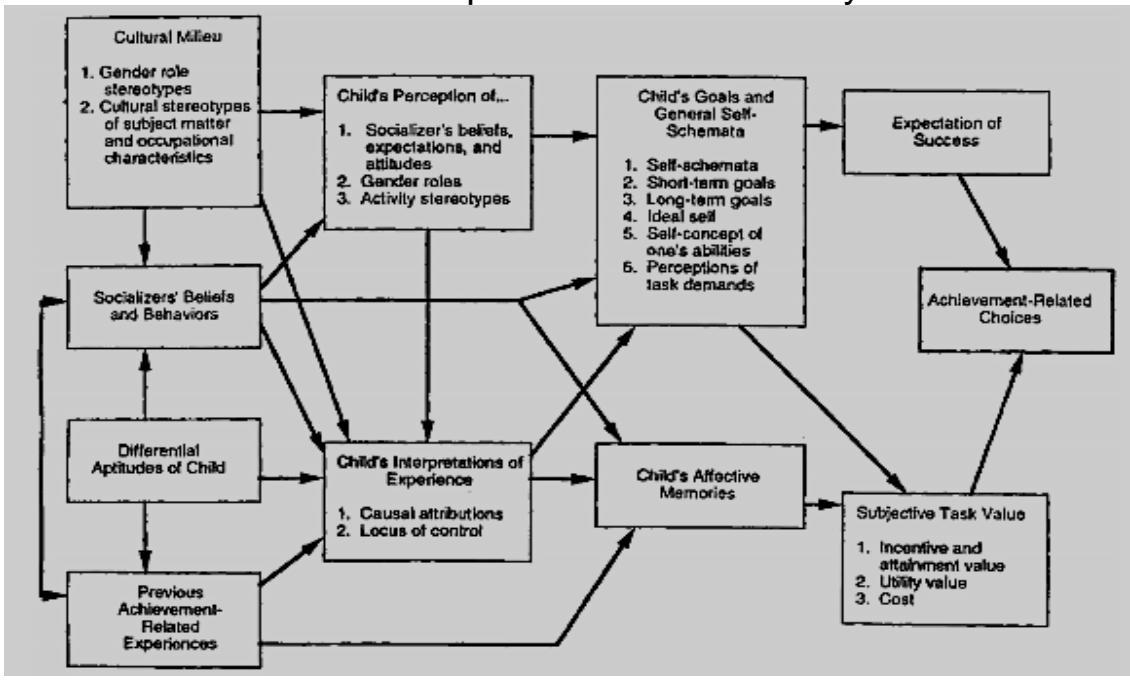

Figure IV The Impact of Values and Expectancy on Learning and Performance, Tahmidatien.L.,\&Krismanto. W., (February, 2019).

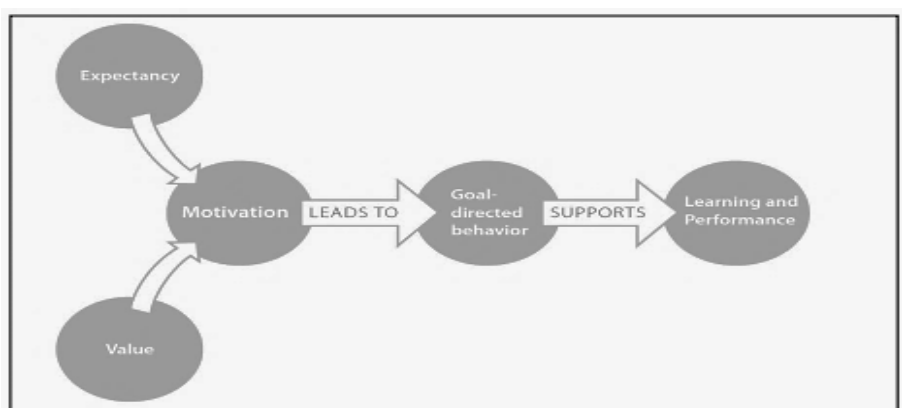


b) Goal theory is purposeful on the aspect of goal setting theory and goal orientation theory which both pathways were impromptu to skill development;

c) Self-determination theory is concerned with preferable complimentary and willingness.

On the contrary aspect of motivation in learning the English language, demotivation has been a crucial aspect in all perspectives of education similar to learning the English language which faces it. Those factors which evoked the backwardness of English language learner enthusiasm are teacher, classmate, textbook and activities, and also student's character aspect, Khusyabaroh. L., Widiati.
U.,\&Anugerahwati. M., (September, 2018).

Inherent, to the case of Vietnams students English language resistances, it founds that the barriers of students resistances in learning the English language are derived from students and teachers side which tangible to the general issues which are the reasons, degree of influences of different demotivate, and then students experiences in overcoming demotivation, Tran. T. T. T., \& Jr. B. B. R., (2007), and the detailed characteristic of demotivation can be seen on page six.In similar to this researcher, he found that the majority of hindering factors which compound in the process of English language learning is influenced by ineffective teacher teaching style, Adara. A. R., (2018).

Figure V The Detail Characteristic of Demotivation

\begin{tabular}{|c|c|}
\hline \multicolumn{2}{|r|}{ Demotive categories } \\
\hline \multicolumn{2}{|c|}{ Grand total } \\
\hline \multicolumn{2}{|c|}{$\begin{array}{l}\text { IA. Attitudes towards English } \\
\text { IE. Experiences of failure or lack of success } \\
\text { IS. Self-esteem } \\
\text { Total } \\
\text { External attributions }\end{array}$} \\
\hline $\begin{array}{l}\text { Teacher- } \\
\text { related } \\
\text { factors }\end{array}$ & $\begin{array}{l}\text { ETb. Teacher behavior } \\
\text { ETc. Teacher competence } \\
\text { ETm. Teaching method } \\
\text { ETg. Grading and assessment } \\
\text { Subtotal }\end{array}$ \\
\hline $\begin{array}{l}\text { Learning } \\
\text { environment }\end{array}$ & $\begin{array}{l}\text { ELc. Classroom atmosphere } \\
\text { ELo. Opportunities to use English } \\
\text { EL1. Learning conditions } \\
\text { ELt. Class time } \\
\text { ELb. Textbook } \\
\text { Subtotal }\end{array}$ \\
\hline Others & $\begin{array}{l}\text { EOb. Obligation } \\
\text { EOn. Negative changes }\end{array}$ \\
\hline
\end{tabular}




\section{METHODS}

This research was conducted descriptive research; which in social, psychology, and education field used this research method on the field of research method, Nassaji. H., (April, 2016). Furthermore, the sample was engaged from the second semester which consisted of twenty-five students through purposive sampling. Moreover, the data collection was collected through two sources were covered:

a) Twenty-five students of second-semester discovery learning tasks who enrolled in English language courses (primary data); b) Besides that on footage data of both responses and participation to the online teaching and learning on chatting group of English language class, email database of the second-semester

opinions in learning the English language, and also the participation in online teaching through live streaming on Facebook (secondary data). In-depth, to analyze those data above, the researcher conducted data that reduces data collection which can be seen below.

Figure VI:

Data Display

\begin{tabular}{|c|c|c|c|c|c|}
\hline \multirow{2}{*}{$\begin{array}{l}\text { To } \\
\text { tal } \\
\text { cla } \\
\text { ss }\end{array}$} & \multirow[b]{2}{*}{$\begin{array}{c}\text { The } \\
\text { Acco } \\
\text { mplis } \\
\text { hment } \\
\text { of } \\
\text { Stude } \\
\text { nts } \\
\text { Disco } \\
\text { very } \\
\text { Learni } \\
\text { ng } \\
\text { Task }\end{array}$} & \multirow{2}{*}{$\begin{array}{l}\text { Online } \\
\text { Chatting } \\
\text { Group } \\
\text { Individual } \\
\text { Participati } \\
\text { on }\end{array}$} & \multicolumn{2}{|c|}{ Email } & \multirow{2}{*}{$\begin{array}{c}\text { Online } \\
\text { Teaching } \\
\text { Process in } \\
\text { Facebook Live } \\
\text { Streaming } \\
\text { (Students } \\
\text { Participation } \\
\text { in Attending } \\
\text { Online Class) }\end{array}$} \\
\hline & & & $\begin{array}{c}\text { (Students } \\
\text { Participatio } \\
\text { n in } \\
\text { Accomplis } \\
\text { h } \\
\text { Discovery } \\
\text { Learning } \\
\text { Task }\end{array}$ & $\begin{array}{l}\text { Students } \\
\text { Opinion } \\
\text { in } \\
\text { Learning } \\
\text { English } \\
\text { Languag } \\
\text { e) }\end{array}$ & \\
\hline 25 & $\begin{array}{c}9 \\
\text { studen } \\
\text { ts }\end{array}$ & 8 students & 9 students & $\begin{array}{c}2 \\
\text { students }\end{array}$ & 1 student \\
\hline
\end{tabular}

\section{RESULTS}

In further, to discuss the data analysis on above, it can be determined that over twenty-five students of the religious music department who enrolled English language course on the second semester; the data analysis was discovered that in four criteria which extended analysis on two subdomain criteria of the fourth criteria, prescribed that:

a) On the first primary data of [the accomplishment of students discovery learningtasks], the 
researcher found that only nine students were able to accomplish their discovery learning task;

b) Besides that to the secondary data collection, on second criteria of [online chatting group participation] researcher found that only eight students were able to participate since online teaching and learning was conducted;

c) Continuously on the secondary data collection of [Email] which synthesized on two data collection analysis, which found that (on page nine):

i. On the domain criterion of students participation in accomplish

discovery learning task, it found that there was a static improvement which nine students were capable to involve on that phase which derived from similar individual to the individual on first data collection analysis;

ii. Besides that, to the criterion of student's opinion in learning the English language, it was found that only two students

acknowledged their opinion in case of the learning process. d) The last criteria that representative of student's participation to involve in online teaching and learning process through Facebook live streaming, it is shown that there was the gradual achievement of that class, which only one person who was able to involve in that online teaching and learning process.

\section{CONCLUSION}

In enlightened to the research finding, the researcher described that form twenty-five students which enrolled English language course, all of the individuals involved in four criteria were common to the same individuals which participated from first to the fourth criteria. It means that there were factors that demotivated the majority of students to participate in each criterion of this research.

Meanwhile, in the second subdomain of student's opinion in learning the English language, both students who were argued about their opinion, which stated that:

a) The process of teaching and learning in English language course in the middle of the pandemic was beneficial to them because of online learning is the bridge to elevate their capabilities and selfmotivation to determine the capacity of discovery learning and or self-study;

b) But also on the other side, they committed that online learning in another way was a barrier to students perspective because in the meantime it has been 
unstable on the network issue;

c) As a classic barrier when in perspective as a studentthey encountered the financial barriers to recharge a mobile-phone credit which significant to influence in purchased its credit (social background);

d) In another fact one of the students said that group chat of the English language was blocked in motivation to participate in online group chat because of inadequate communication in teaching and learning information distribution on group chat;

e) The other one said that he preferred to sufficient when following the conventional or traditional teaching and learning situation in class rather than followed an online course.

In short, based on the research findings, the researcher concluded that those factors which compulsory in English language learners were influence by intrinsic motivation, and other domain criteria obstructed by extrinsic motivation. The other fact is the majority of students who unable to participate in all criteria, were stated on originate factors which referred to intrinsic motivation that can be described by the fact of they were unable to adequate some information to the reason of uninvolved in all teaching and learning meetings.

In the future, for further research it is considerable to integrate the secondary theory which relates to several learning grounded study that related in compound of social learning, conditional learning, learning environmental theories, adult learning-modern adult learning, and self-direct learning; which in purpose to determine the concept of individual learning motivation that accordance to the engagement of university students improvement and self-motivation to the sustainable learning English language development.

\section{REFERENCES}

Abadi, N. (2014, January). The Role of Intrinsic and Extrinsic Motivation on Second Language Acquisition in TEFL Students [special issue]. Researchgate.

Adara, A. R. (2019). Investigating the Difference in Demotivation Factors: A Case Study of Two Groups of Indonesian EFL Learners, 4(2), 1-14.

Adara, A. R. (2018). Demotivating Factors of IndonesianCollege Students to Learn English as a Foreign Langauge. Sukma: Jurnal Pendidikan, 2(1), 1-24. DOI: https://doi.org/10.32533/02101.2018

Gopalan, V.\& Abubakar. A. J. (2017, October). A Review of the Motivation Theories in Learning [Conference Paper]. AIP Conference Proceedings. DOI: 10.1063/1.5005376. 
Khusyabaroh, L., Widiati. U., \& Anugerahwati, M. (2018, September). Demotivating Factors in Learning English: Students' Perceptions. Jurnal Pendidikan Humonaria, 6(3), 134-144.

Legault, L. (2016, November). Intrinsic and Extrinsic Motivation. Springer International Publishing AG 2016, 1-5. DOI: 10.1007/978-3-319-280998_1139-1

Mauludin, A. L. (2015, September). The Important of Non-Native English Speaker Teacher in the Context of English as a Foreign Language. Transformatika, 11 (2), 134-144.

Mappiasse, S. S., \& Shies, B. J. A. (2014, September). Evaluation of English as a Foreign Language and Its Curriculum in Indonesia: A Review. English Language Teaching, 7 (10), 1-11. DOI: 10.5539/elt.v7n10p113

Nguyen, H. \& Terry, R. D. (2017). English Learning Strategies among EFL Learners: A Narrative Approach, 3(1), 1-16.

Nassaji, H. (2015, August). Qualitative and Descriptive Research: Data Type Versus Data Analysis.Language Teaching Research,19(2), 129-132. sagepub.co.uk/journalsPermissions.navDOI: $10.1177 / 1362168815572747$

Oletić, A. \& Ilić, N. (2014, December).Intrinsic and Extrinsic Motivation for Learning English as a Foreign Language. ELTA Journal, 2(2), 23-38.

Romah, Z. (2005, February). English as a Global Language: Its Historical Past and Its Future. IAIN Sunan Ampel, Surabaya.

Tanjung. Z. F. (2018, April). Language Learning Strategies in English as a Foreign Language Classroom in Indonesian Higher Education Context. LLT Journal: A Journal on Language and Language Teaching, 25799533 (21), 1-19. doi.org/10.24071/llt.2018.Suppl2106

Tohidi, H. \&Jabbari, M. M. (2012, December). The Effects of Motivation in Education. Social and Behavioral Sciences 31, 820 - 824. DOI: 10.1016/j.sbspro.2011.12.148

Trang, T. T. \&Baldauf Jr. B. R. (2007). Demotivation: Understanding Resistance to English Language Learning - The Case of Vietnamese Students, 4(1), 79-105.

Tahmidatien, L. \&Krismanto. W.Menumbuhkan Motivasi Belajar Dari Aspek Value, Expectancydan Self Regulated Learning.Jurnal Publikasi Pendidikan, 9(1), 87-97.

Wigfield, A. (2000). Expectancy-Value Theory of Achievement Motivation. Contemporary Educational Psychology25, 68-81. doi:10.1006/ceps.1999.1015 